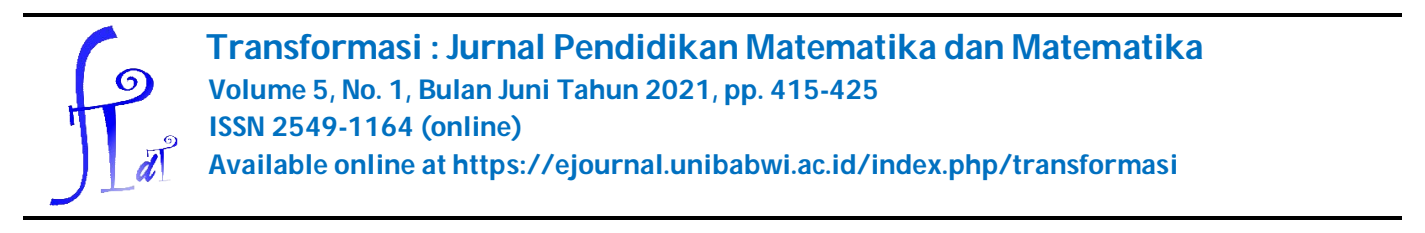

\title{
ANALISIS SURVIVAL LAMA WAKTU SEMBUH PASIEN COVID-19 DENGAN METODE KAPLAN-MEIER DAN LOG-RANK DI KABUPATENJEMBER
}

\author{
Wigid Hariadi ${ }^{1}$, Sulantari ${ }^{2}$ \\ 1,2 FP MIPA, IKIP PGRI JEMBER \\ email korespondensi : wigid.hariadi@gmail.com
}

Diterima : (18-10-2020), Revisi: (17-03-2021), Diterbitkan : (07-05-2021)

\begin{abstract}
ABSTRAK
Analisis survival adalah satu analisis data statistika yang bertujuan untuk melakukan analisis fungsi survival (waktu sembuh). Sampai tanggal 23 Oktober 2020 di Kabupaten Jember tercatat bahwa terdapat sebesar 1.098 pasien terkonfirmasi positif Covid-19, sebanyak 939 (85,52\%) pasien sudah dinyatakan sembuh, dan 55 (5,01\%) pasien dinyatakan meninggal. Hal ini menunjukkan bahwa virus Covid-19 ini berbahaya bagi masyarakat di Kabupeten Jember. Namun demikian angka kesembuhannya juga cukup tinggi, yaitu 85,52\%. Analisis survival ini dilakukan untuk mengatahui waktu sembuh pasien Covid-19 di Kabupaten Jember, dengan menggunakan uji Kaplan-Meier dan uji Log-Rank. Uji Kaplan-Meier digunakan untuk menghitung estimasi fungsi survival (waktu sembuh) pasien Covid-19, dan uji Log-Rank digunakan untuk menguji adanya perbedaan fungsi survival $(\mathrm{S}(\mathrm{t})$ ) waktu sembuh pasien Covid-19 pada pasien laki-laki dan perempuan. Data yang digunakan adalah data pasien Covid-19 di Kabupaten Jember sejak Maret 2020 sampai dengan 23 Oktober 2020. Hasil penelitian menunjukkan bahwa median fungsi survival waktu sembuh pasien Covid-19 di Kabupaten Jember adalah 16 hari perawatan. Berdasarkan uji Log-Rank dengan $\alpha=0,05$, disimpulkan bahwa terdapat perbedaan yang signifikan antara fungsi survival $\mathrm{S}(\mathrm{t})$ lama waktu sembuh pasien laki-laki dan pasien perempuan, dengan waktu sembuh pasien perempuan lebih cepat dibandingkan pasien laki-laki.
\end{abstract}

Kata kunci : Covid-19, Jember, Analisis Survival, Uji Kaplan-Meier, Uji Log-Rank 


\begin{abstract}
Survival analysis is a statistical data analysis that aims to perform a survival function analysis (recovery time). Until 23 October 2020 in Jember, it was recorded that there were 1,098 patients who were confirmed positive for Covid-19, as many as 939 (85.52\%) patients had been declared cured, and 55 (5.01\%) patients were declared dead. This shows that the Covid-19 virus is dangerous for the people in Jember. However, the recovery rate is also quite high, namely $85.52 \%$. This survival analysis was carried out to determine the recovery time of covid-19 patients in Jember, using the Kaplan-Meier test and the Log-Rank test. The Kaplan-Meier test is used to calculate the estimated survival function (recovery time) of Covid-19 patients, and the Log-Rank test is used to test whether there is a difference in survival function $(\mathrm{S}(\mathrm{t})$ ) recovery time of Covid-19 patients in male patients and women. The data used were data on Covid-19 patients in Jember from March 2020 to October 23, 2020. The results showed that the median survival function for Covid-19 patients in Jember was 16 days of treatment. Based on the Log-Rank test with $\alpha=0.05$, it was concluded that there was a significant difference between the survival function $\mathrm{S}(\mathrm{t})$ length of recovery time for male patients and female patients, where female patients have a faster recovery time than male patients.
\end{abstract}

Key words : Covid-19, Jember, Survival Analysis, Kaplan-Meier Test, Log-Rank Test

\title{
Pendahuluan
}

Menurut Kementerian Kesehatan Republik Indonesia (2020), Coronavirus (CoV) adalah keluarga besar virus yang menyebabkan penyakit mulai dari gejala ringan sampai berat. Adapun novel coronavirus (2019-nCoV) atau dikenal juga sebagai Covid-19 adalah virus jenis baru yang belum pernah diidentifikasi sebelumnya pada manusia. Virus ini biasanya menyebabkan penyakit pada infeksi saluran pernafasan. Mulai flu biasa hingga penyakit yang serius seperti MERS dan Sindrom Pernafasan Akut Berat/ SARS. Coronavirus ditemukan pada manusia di Wuhan Cina pada Desember 2019, selanjutnya diberi nama Severe Acute Respiratory Syndrome Coronavirus 2 (SARS-COV2), yang kemudian menjadi penyakit Coronavirus Disease-2019 (COVID-19). Menurut Fadli (2020), Coronavirus menyebabkan infeksi saluran pernapasan atas ringan hingga sedang, seperti penyakit flu. Adapun kelompok yang rentan terinfeksi virus corona adalah orang lanjut usia (lansia), orang dengan riwayat penyakit tertentu, tenaga medis di rumah sakit, serta anak-anak (Ikhsania, 2020).

Jumlah pasien terinfeksi virus Corona juga semakin tinggi dengan jumlah kema- 
tian yang tidak rendah. Menurut KemenkesRI (2020), pertanggal 23 Oktober 2020 jumlah pasien positif Corona sebesar 381.910 pasien, dengan jumlah pasien yang sembuh sebesar 305.100 pasien atau sebesar 79,89\% dan jumlah pasien yang meninggal sebanyak 13.077 pasien atau sebesar 3,42\%. Hal ini memperlihatkan bahwa virus corona cukup berbahaya bagi manusia. Jember menjadi salah satu daerah di Jawa Timur dengan jumlah pasien terkonfirmasi yang tinggi. Pertangal 23 Oktober 2020, tercatat bahwa sebesar 1.098 pasien terkonfirmasi positif Covid-19, dengan $939(85,52 \%)$ pasien sudah dinyatakan sembuh, dan $55(5,01 \%)$ pasien dinyatakan meninggal (Pemkabjember, 2020).

Metode Kaplan-Meier merupakan modifikasi dari fungsi yang digunakan untuk menangani masalah data tak lengkap (Lawless, 2003). Kaplan-Meier adalah uji statistika yang digunakan untuk menghitung estimasi fungsi survival S(t). Metode Kaplan-Meier mampu memberikan representasi grafis tentang distribusi survival/ tahan hidup (Cook, 2008). Sedangkan uji Log-Rank digunakan untuk membandingkan 2 kelompok yang berkaitan, dengan kondisi yang berbeda. Melalui uji Log-Rank dapat diketahui apakah ke-2 sampel tersebut memiliki fungsi survival S(t) yang sama atau tidak. Pada beberapa penelitian sebelumnya, Uji Kaplan-Meier dapat memberikan gambaran bahwa peluang survival pasien jantung koroner di RSUD Undata Palu masih sedang berkisar antar 0,6 hingga 1 (Suhartini, dkk., 2018).

Melihat tingginya kasus positif Covid-19 di Kabupaten Jember, maka penulis ingin melakukan penelitian mengenai analisis survival lama waktu sembuh pasien Covid-19 di Kabupaten Jember dengan menggunakan metode Kaplan-Meier dan Log-Rank. Tujuan penelitian ini adalah untuk mengetahui estimasi fungsi survival (lama waktu sembuh) pasien Covid-19 di Kabupaten Jember, dan mengetahui adanya perbedaan lama waktu sembuh antara pasien laki-laki dan pasien perempuan.

\section{Metode Penelitian}

Penelitian dilakukan di wilayah Kabupaten Jember, Jawa Timur, sejak tanggal 27 Maret 2020 sampai tanggal 23 Oktober 2020. Sasaran penelitian ini adalah pasien Covid-19 yang dinyatakan sembuh. Data yang digunakan merupakan data sekunder yang berisi data pasien Covid-19 di wilayah Kabupaten Jember yang diperoleh melalui data publikasi Pemkab Jember (Instagram@pemkabjember). Populasi da- 
lam penelitian ini adalah seluruh pasien Covid-19 di Kabupaten Jember yang dinyatakan sembuh, sebanyak 939 pasien. Sampel dalam penelitian ini diambil sebanyak 76 pasien Covid-19 yang telah dinyatakan sembuh. Pengambilan sampel menggunakan rumus Slovin, dengan menggunakan tingkat signifikansi $(\alpha)$ sebesar 0,11 , dan penentuan sampel dilakukan melalui sampling acak sederhana. Rumus Slovin yang digunakan untuk menentukan ukuran sampel minimal adalah sebagai berikut :

$$
n=\frac{N}{1+N\left(\alpha^{2}\right)}
$$

Dengan $: \mathrm{n}$ : adalah sampel minimal

$\mathrm{N}$ : ukuran populasi

$\alpha \quad$ : tingkat signifikansi

Uji Kaplan-Meier dan uji Log Rank digunakan untuk menganalisis data. Uji Kaplan-Meier ditujukan untuk menentukan estimasi fungsi survival (S(t)), dan menampilkan grafik fungsi survival $(\mathrm{S}(\mathrm{t}))$. Fungsi survival $(\mathrm{S}(\mathrm{t})$ ) digunakan untuk menyatakan probabilitas suatu objek sampai tidak terjadinya suatu event. $\mathrm{S}(\mathrm{t})$ merupakan estimasi fungsi survival atau probabilitas waktu survival lebih besar dari t, dinyatakan sebagai berikut :

$$
S(t)=P(T>t)=1-F(t)=1-P(T \leq t)
$$

Fungsi survival untuk suatu interval waktu adalah proporsi jumlah subjek survive pada awal interval dikurangi jumlah kegagalan dalam interval tersebut:

$$
\hat{S}\left(t_{i}\right)=\frac{N_{i-1}-d_{i}}{N_{i-1}}
$$

Uji Log-Rank merupakan uji untuk membandingkan dua kelompok yang berkaitan, dengan kondisi yang berbeda. Melalui uji Log-Rank dapat diketahui adanya fungsi survival S(t) yang sama secara statistik antara kedua kelompok tersebut. Uji Log-Rank dilakukan untuk menguji hipotesis:

Ho : $\mathrm{S}_{1}(\mathrm{t})=\mathrm{S}_{2}(\mathrm{t})$ (tidak terdapat perbedaan yang signifikan antara 2 fungsi survival)

$\mathrm{H}_{1}: \mathrm{S}_{1}(\mathrm{t}) \neq \mathrm{S}_{2}(\mathrm{t})$ (terdapat perbedaan yang signifikan antara 2 fungsi survival) Daerah kritis adalah tolak $\mathrm{H}_{0}$ jika $\mathrm{P}$-value < tingkat signifikansi $(\alpha)$. 


\section{Hasil dan Pembahasan}

\section{Analisis Metode Kaplan-Meier}

Metode Kaplan-Meier digunakan untuk mengetahui fungsi survival lama waktu sembuh (S(t)) pasien Covid-19 terhadap suatu perlakuan (perawatan). Berikut ini akan ditampilkan tabel data sampel dan plot data antar kejadian waktu sembuh pasien covid-19 dari 76 pasien yang terpilih sebagai sampel. Yang menjadi kriteria sampel adalah pasien Covid-19 di Kabupaten Jember yang diketahui tanggal dinyatakan positif Covid-19 dan tanggal dinyatakan sembuhnya. Lama waktu sembuh adalah lama waktu (hari) perawatan pasien mulai dinyatakan positif hingga dinyatakan sembuh Covid-19. Adapun data dan plot data antar kejadiannya tersaji pada Tabel 1, dan Gambar 1 dibawah ini.

Tabel 1. Data Sampel Pasien Covid-19 di Kabupaten Jember yang Dinyatakan Sembuh

\begin{tabular}{|c|c|c|c|c|c|c|c|c|c|}
\hline No & PASIEN KE- & STATUS & \begin{tabular}{|c|} 
LAMA PERAWATAN \\
SAMPAI SEMBUH (HARI) \\
\end{tabular} & JENIS KELAMIN & No & PASIEN KE- & STATUS & \begin{tabular}{|c|} 
LAMA PERAWATAN \\
SAMPAI SEMBUH (HARI)
\end{tabular} & JENIS KELAMIN \\
\hline 1 & 1 & Sembuh & 12 & * & 39 & 70 & Sembuh & 16 & laki-laki \\
\hline 2 & 2 & Sembuh & 46 & * & 40 & 78 & Sembuh & 15 & laki-laki \\
\hline 3 & 10 & Sembuh & 14 & * & 41 & 79 & Sembuh & 15 & perempuan \\
\hline 4 & 11 & Sembuh & 14 & * & 42 & 92 & Sembuh & 11 & * \\
\hline 5 & 3 & Sembuh & 38 & * & 43 & 99 & Sembuh & 8 & * \\
\hline 6 & 5 & Sembuh & 41 & * & 44 & 62 & Sembuh & 23 & * \\
\hline 7 & 6 & Sembuh & 44 & * & 45 & 80 & Sembuh & 19 & perempuan \\
\hline 8 & 8 & Sembuh & 36 & * & 46 & 89 & Sembuh & 16 & * \\
\hline 9 & 26 & Sembuh & 14 & * & 47 & 96 & Sembuh & 11 & - \\
\hline 10 & 18 & Sembuh & 22 & perempuan & 48 & 104 & Sembuh & 9 & * \\
\hline 11 & 21 & Sembuh & 24 & laki-laki & 49 & 86 & Sembuh & 20 & perempuan \\
\hline 12 & 23 & Sembuh & 24 & laki-laki & 50 & 110 & Sembuh & 7 & * \\
\hline 13 & 19 & Sembuh & 31 & $*$ & 51 & 14 & Sembuh & 28 & $*$ \\
\hline 14 & 20 & Sembuh & 31 & laki-laki & 52 & 83 & Sembuh & 24 & laki-laki \\
\hline 15 & 22 & Sembuh & 31 & laki-laki & 53 & 103 & Sembuh & 14 & * \\
\hline 16 & 15 & Sembuh & 38 & laki-laki & 54 & 39 & Sembuh & 38 & $*$ \\
\hline 17 & 48 & Sembuh & 13 & $*$ & 55 & 54 & Sembuh & 33 & laki-laki \\
\hline 18 & 49 & Sembuh & 12 & perempuan & 56 & 130 & Sembuh & 4 & - \\
\hline 19 & 50 & Sembuh & 12 & laki-laki & 57 & 109 & Sembuh & 15 & * \\
\hline 20 & 57 & Sembuh & 11 & * & 58 & 68 & Sembuh & 31 & * \\
\hline 21 & 63 & Sembuh & 8 & * & 59 & 33 & Sembuh & 47 & $*$ \\
\hline 22 & 65 & Sembuh & 7 & * & 60 & 158 & Sembuh & 7 & $*$ \\
\hline 23 & 36 & Sembuh & 18 & $*$ & 61 & 29 & Sembuh & 51 & $*$ \\
\hline 24 & 37 & Sembuh & 18 & * & 62 & 108 & Sembuh & 22 & * \\
\hline 25 & 47 & Sembuh & 14 & * & 63 & 127 & Sembuh & 13 & $\cdot$ \\
\hline 26 & 66 & Sembuh & 10 & * & 64 & 30 & Sembuh & 52 & * \\
\hline 27 & 91 & Sembuh & 3 & $*$ & 65 & 32 & Sembuh & 52 & $\cdot$ \\
\hline 28 & 34 & Sembuh & 23 & perempuan & 66 & 46 & Sembuh & 45 & $*$ \\
\hline 29 & 35 & Sembuh & 23 & $*$ & 67 & 52 & Sembuh & 44 & 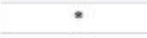 \\
\hline 30 & 58 & Sembuh & 17 & $*$ & 68 & 53 & Sembuh & 44 & $*$ \\
\hline 31 & 61 & Sembuh & 16 & $*$ & 69 & 56 & Sembuh & 43 & $*$ \\
\hline 32 & 28 & Sembuh & 2 & $*$ & 70 & 166 & Sembuh & 6 & $*$ \\
\hline 33 & 60 & Sembuh & 20 & $*$ & 71 & 169 & Sembuh & 6 & $*$ \\
\hline 34 & 67 & Sembuh & 15 & perempuan & 72 & 167 & Sembuh & 7 & $\bullet$ \\
\hline 35 & 84 & Sembuh & 13 & perempuan & 73 & 173 & Sembuh & 7 & * \\
\hline 36 & 87 & Sembuh & 11 & * & 74 & 174 & Sembuh & 7 & $\bullet$ \\
\hline 37 & 88 & Sembuh & 11 & * & 75 & 175 & Sembuh & 7 & $*$ \\
\hline 38 & 38 & Sembuh & 27 & $*$ & 76 & 176 & Sembuh & 7 & $=$ \\
\hline
\end{tabular}

Sumber: Peta Sebaran Covid-19 di Kabupaten Jember (instagram@PemkabJember) 


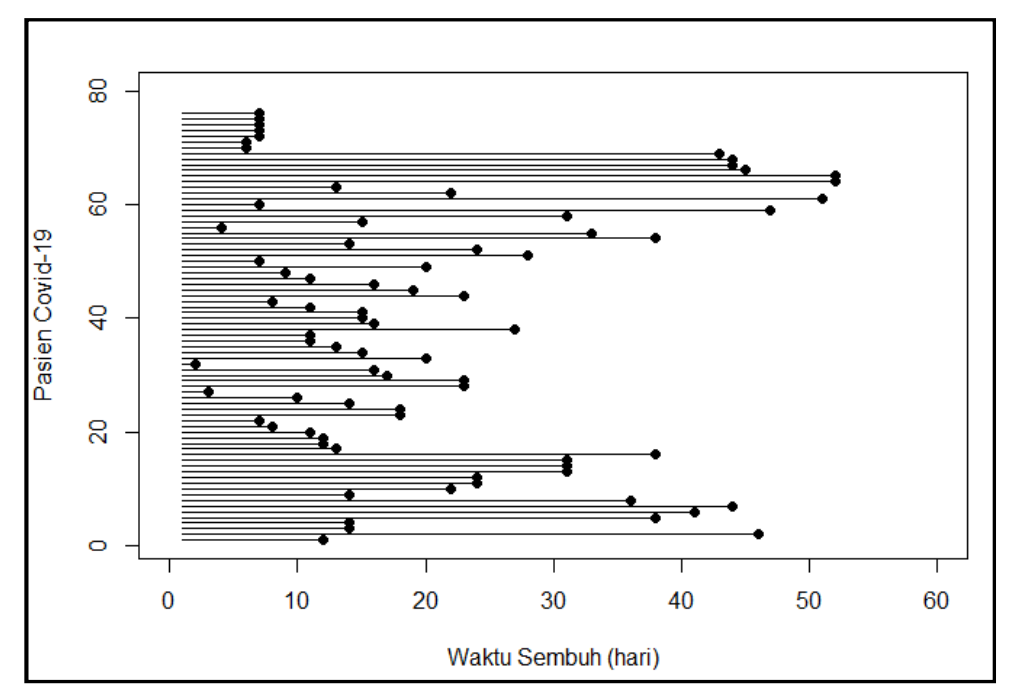

Gambar 1. Plot Data Antar Kejadian Waktu Sembuh Pasien Covid-19 yang Menjadi Sampel

Gambar 1 menunjukkan data antara kejadian waktu sembuh pasien covid-19 di wilayah Kabupaten Jember. Terlihat bahwa waktu sembuh pasien covid-19 berbeda-beda, dengan waktu sembuh tercepat adalah 2 hari masa perawatan dan waktu sembuh terlama adalah 44 hari masa perawatan. Adapun hasil estimasi Uji Kaplan-Meier ditampilkan pada Gambar 2.

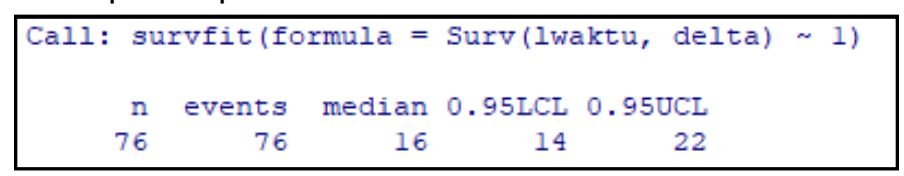

Gambar 2. Estimasi Kaplan-Meier Waktu Sembuh Pasien Covid-19 di Kabupaten Jember

Gambar 2 menampilkan ouput hasil estimasi Kaplan-Meier. Berdasarkan output tersebut dapat diketahui bahwa secara umum lama waktu sembuh pasien covid-19 memiliki median sebesar 16 hari perawatan, dengan batas bawah median konfiden intervalnya adalah 14 hari perawatan dan batas atas median konfiden intervalnya adalah 22 hari.

Gambar 3 berikut menampilkan estimasi fungsi survival $\mathrm{S}(\mathrm{t})$ lama waktu sembuh Pasien Covid-19 di Kabupeten Jember, sedangkan Gambar 4, merupakan penyajian bentuk grafik dari fungsi survival $\mathrm{S}(\mathrm{t})$. 


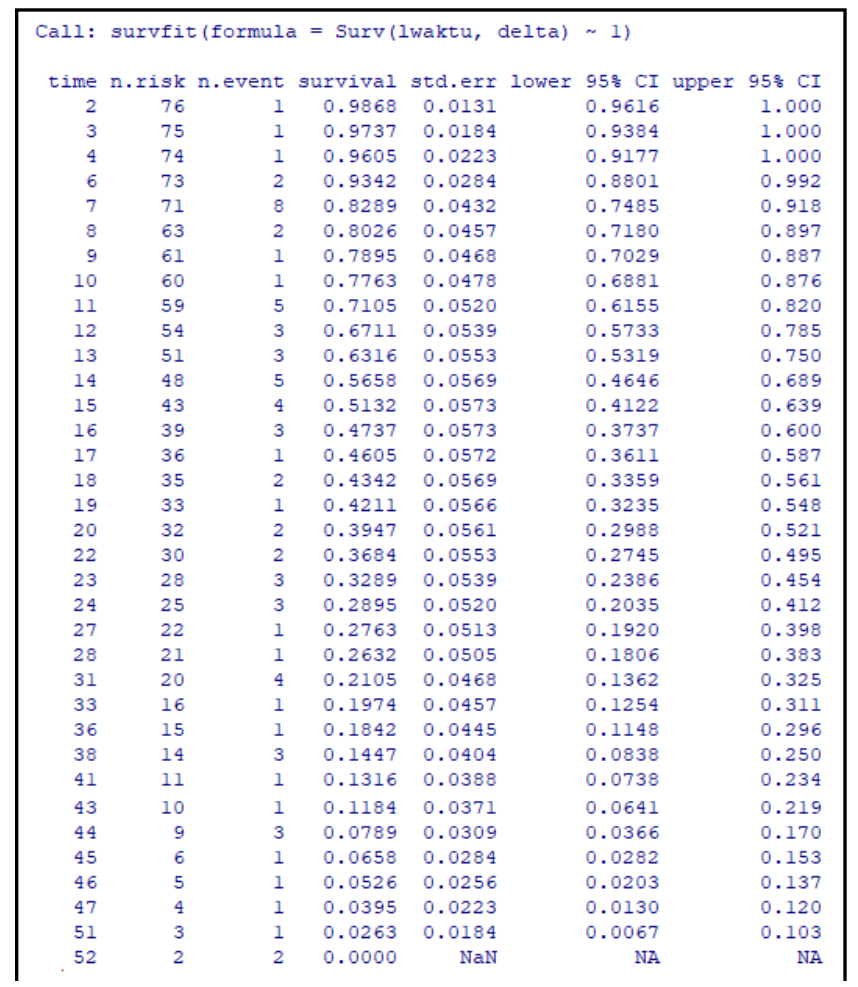

Gambar 3. Estimasi Fungsi Survival S(t) Waktu Sembuh Pasien Covid-19 di Kabupaten

Jember

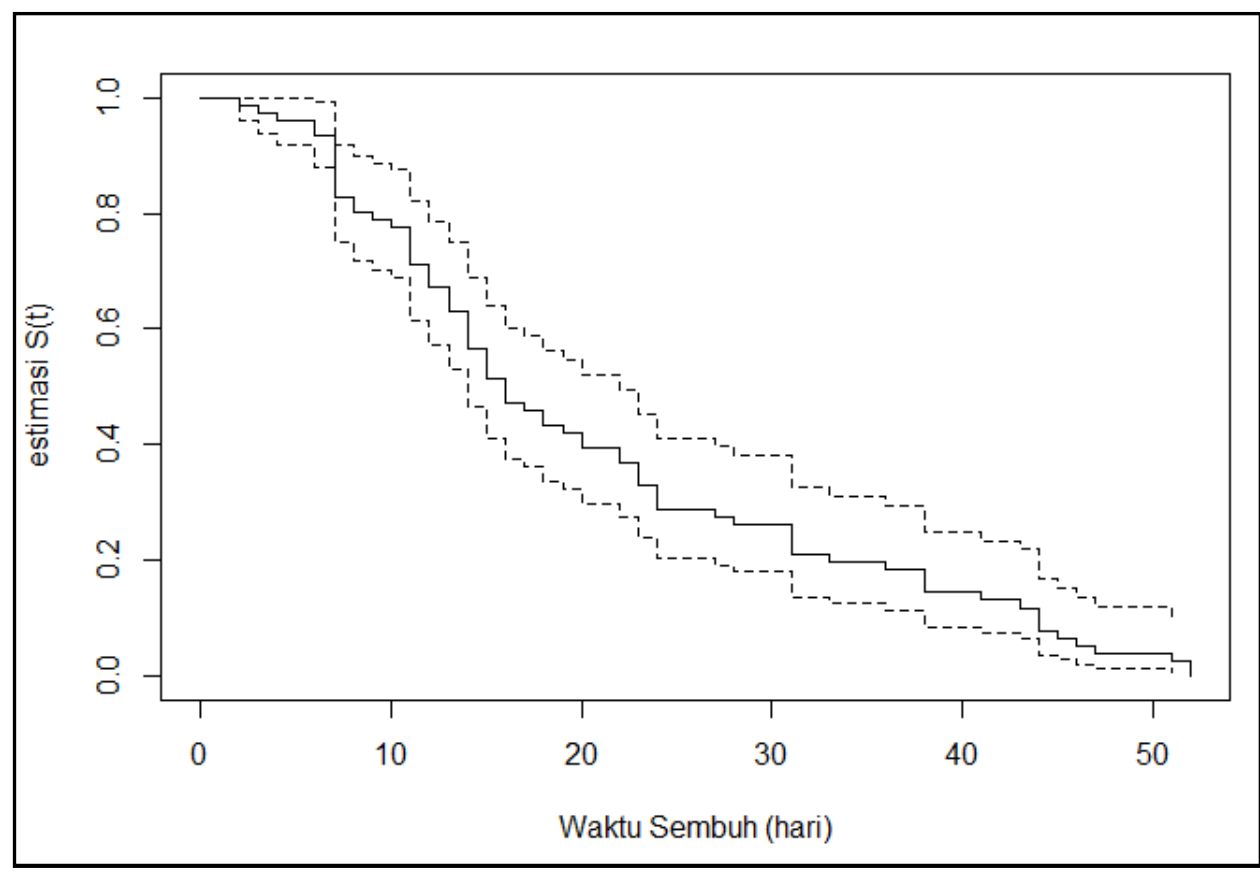

Gambar 4. Grafik Kaplan-Meier Fungsi Waktu Sembuh Pasien Covid-19 di Kabupaten Jember 
Grafik pada gambar 4 menunjukkan fungsi survival $(\mathrm{S}(\mathrm{t}))$ dari lama waktu sembuh pasien Covid-19 di Kabupaten Jember. Berdasarkan gambar 2, juga dapat diketahui bahwa median data adalah 16. Sehingga dapat dikatakan bahwa median lama waktu sembuh pasien Covid-19 di Kabupaten Jember adalah 16 hari perawatan. Adapun waktu sembuh tercepat sekitar 2 hari masa perawatan, dan waktu sembuh terlama sekitar 52 hari masa perawatan. Sehingga jika terdapat pasien yang masa perawatannya lebih dari 52 hari namun belum juga sembuh, maka hal itu perlu menjadi perhatian lebih bagi pihak terkait.

\section{Analisis Kaplan-Meier Untuk Faktor Jenis Kelamin Pasien}

Dari 76 orang yang menjadi sampel, tidak semua dapat digunakan untuk analisis Kaplan-Meier faktor Jenis Kelamin. Hal ini karena tidak lengkapnya informasi yang dipublikasi oleh Pemkab Jember. Sehingga untuk analisis ini sampel yang digunakan adalah sampel yang tercantumkan informasi jenis kelamin pasien, yaitu sebanyak 18 pasien, dengan pasien laki-laki sebanyak 10 orang dan pasien perempuan sebanyak 8 orang. Berikut ini adalah Uji Kaplan-Meier untuk pasien Covid-19 yang berjenis kelamin laki-laki. Hasil estimasi dari fungsi survival $(\mathrm{S}(\mathrm{t})$ ) serta grafik dari fungsi survival $(\mathrm{S}(\mathrm{t})$ ) lama waktu sembuh Pasien Covid-19 pada pasien laki-laki dapat diketahui pada gambar 5 .

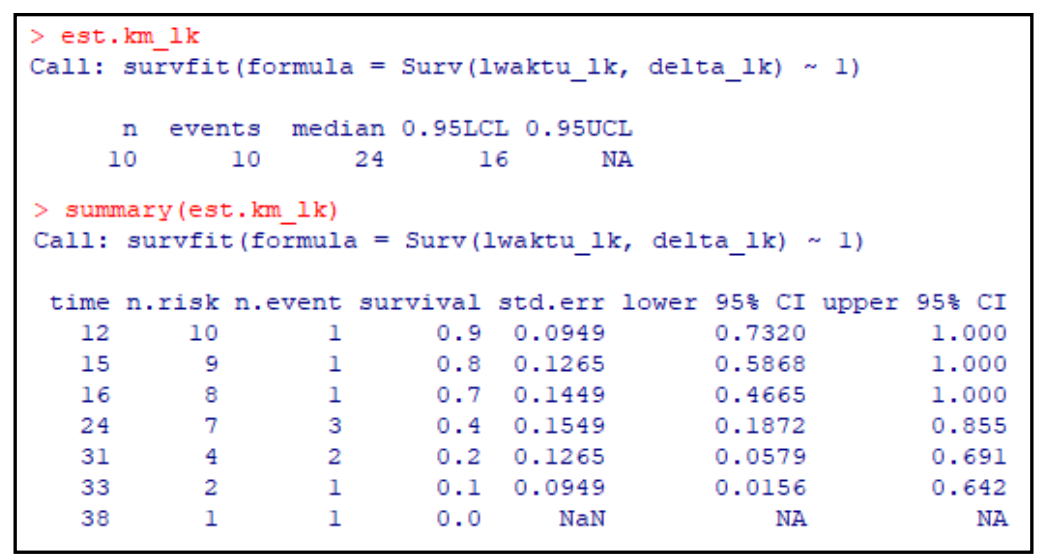

Gambar 5. Estimasi Kaplan-Meier Waktu Sembuh Pasien Covid-19 Jenis Kelamin Laki-laki

Gambar 5 diatas menunjukkan estimasi Kaplan-Meier untuk pasien laki-laki yang menunjukkan bahwa fungsi survival S(t) dari waktu sembuh pasien Covid-19 laki-laki memiliki median 24 hari perawatan, dengan waktu sembuh tercepat sekitar 12 hari masa perawatan, dan waktu sembuh terlama sekitar 38 hari masa 
perawatan.

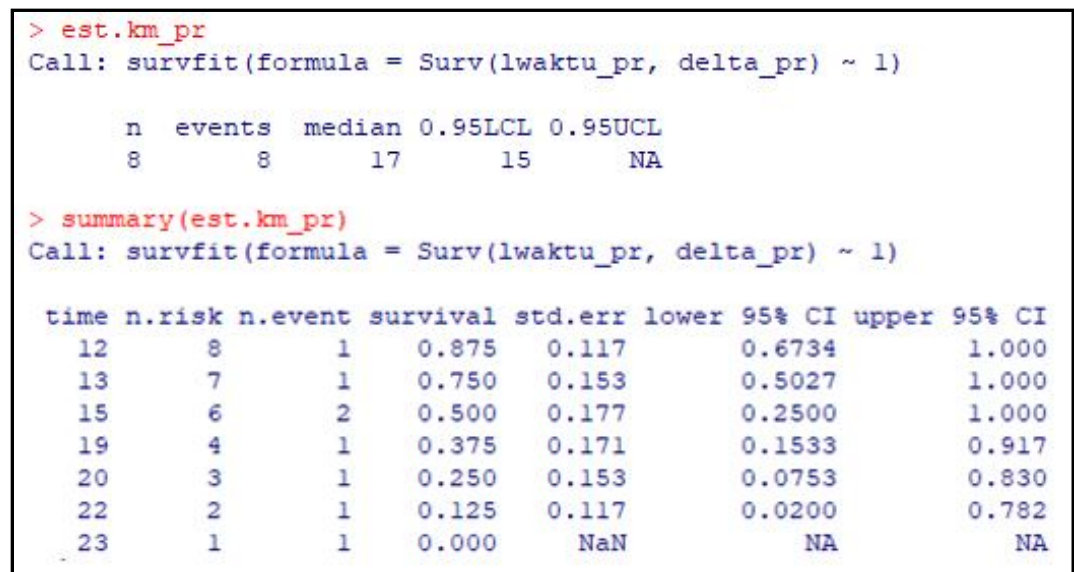

Gambar 6. Estimasi Kaplan-Meier Waktu Sembuh Pasien Covid-19 Perempuan

Gambar 6 diatas menunjukkan estimasi Kaplan-Meier untuk pasien perempuan. Hasil estimasi menunjukkan bahwa fungsi survival S(t) dari waktu sembuh pasien Covid-19 perempuan memiliki median 17 hari perawatan, dengan waktu sembuh tercepat sekitar 12 hari masa perawatan dan waktu sembuh terlama sekitar 23 hari masa perawatan.

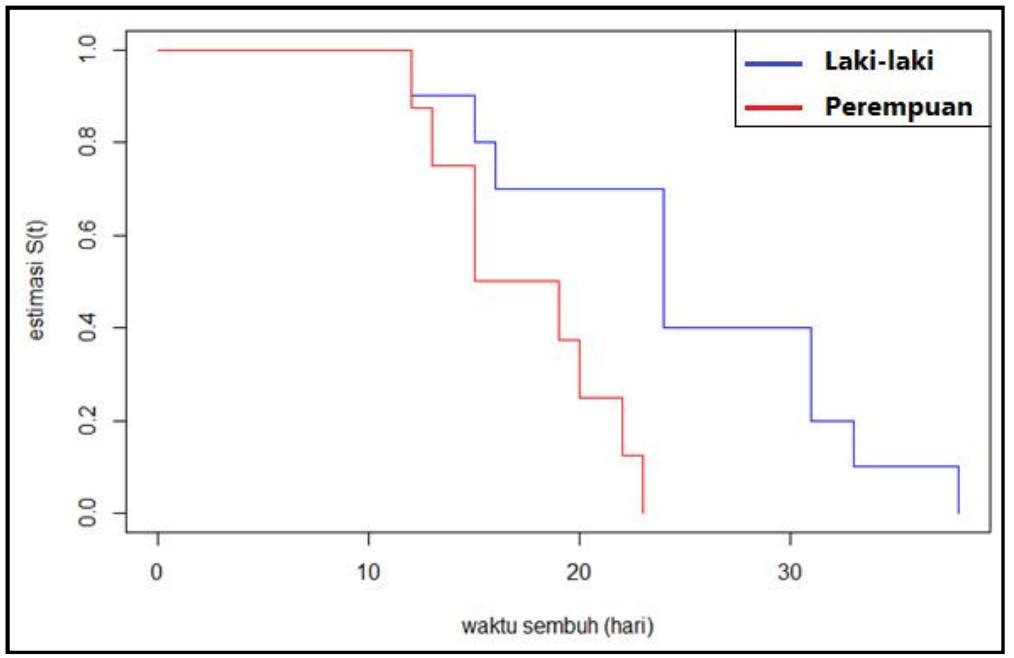

Gambar 7. Kurva Kaplan-Meier Waktu Sembuh Pasien Covid-19 Faktor Jenis Kelamin Gambar 7 diatas menunjukkan bahwa pasien perempuan memiliki peluang tahan hidup/peluang sembuh dari Covid-19 lebih cepat dibandingkan pasien laki-laki. Karena kurva waktu sembuh pasien perempuan (grafik warna merah) ada dibawah kurva waktu sembuh pasien laki-laki (grafik warna biru). Artinya pasien perempuan memiliki peluang sembuh lebih besar dibandingkan pasien laki-laki. 


\section{Uji Log-Rank}

Uji log-rank antara pasien laki-laki dengan pasien perempuan dilakukan untuk mengetahui adanya kesamaan fungsi survival lama waktu sembuh pasien covid-19 antara pasien laki-laki dengan pasien perempuan. Pasien laki-laki diberi simbol 1 dan pasien perempuan diberi simbol 0 .

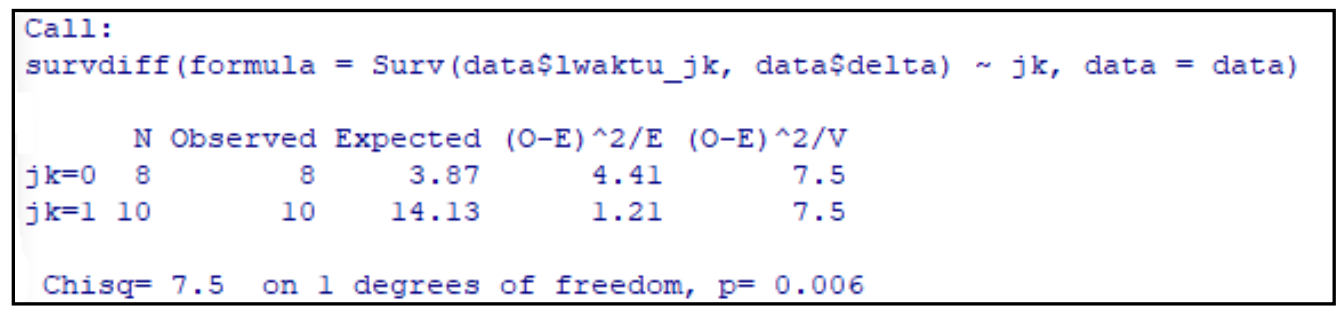

Gambar 8. Estimasi Uji Log-Rank Waktu Sembuh Pasien Covid-19 Menurut Jenis Kelamin

Berdasarkan output pada Gambar 8 diatas, dilakukan pengujian log-rank antara pasien laki-laki dan pasien perempuan. Hipotesis yang digunakan adalah :

Ho : $\mathrm{S}_{1}(\mathrm{t})=\mathrm{S}_{2}(\mathrm{t})$ (Tidak terdapat perbedaan waktu sembuh antara waktu sembuh pasien laki-laki dan pasien perempuan)

$\mathrm{H}_{1}: \mathrm{S}_{1}(\mathrm{t}) \neq \mathrm{S}_{2}(\mathrm{t})$ (Terdapat perbedaan waktu sembuh antara waktu sembuh pasien laki-laki dan pasien perempuan)

Dengan tingkat signifikansi $(\alpha)$ sebesar 5\%, dapat diambil keputusan untuk menolak Ho dimana nilai p-value $(0,006)<\alpha$. Karena Ho ditolak maka dapat disimpulkan bahwa terdapat perbedaan yang signifikan antara fungsi survival $\mathrm{S}(\mathrm{t})$ lama waktu sembuh pasien Covid-19 laki-laki dan perempuan. Pasien perempuan memiliki waktu sembuh yang lebih cepat dibandingkan pasien laki-laki.

\section{Kesimpulan}

Berdasarkan hasil penelitian dan analisis data dapat disimpulkan bahwa fungsi survival S(t) lama waktu sembuh pasien Covid-19 di Kabupaten Jember memiliki median 16 hari perawatan, dengan fungsi survival S(t) lama waktu sembuh pasien Covid-19 untuk pasien berjenis kelamin laki-laki di Kabupaten Jember memiliki median 24 hari perawatan dan fungsi survival S(t) lama waktu sembuh pasien Covid-19 untuk pasien berjenis kelamin perempuan di Kabupaten Jember memiliki median 17 hari perawatan. Secara signifikan, terdapat perbedaan lama waktu sembuh pasien covid-19 di Kabupaten Jember. Pasien berjenis kelamin perempuan diketahui lebih cepat sembuh dibandingkan pasien berjenis kelamin laki-laki. 


\section{Ucapan Terimakasih}

Ucapan terimakasih ditujukan pada LPPM IKIP PGRI Jember yang telah mendukung peneliti untuk dapat melaksanakan penelitian ini.

\section{Daftar Pustaka}

Cook, A.(2008). Kaplan Meier Estimate of S(t). Singapore : National University of Singapore

Fadli, R. (2020). Coronavirus. https:/ / www.halodoc.com/ kesehatan/ coronavirus. 30 Agustus 2020.

Harlan, J. (2017). Analisis Survival. Jakarta:Penerbit Gunadarma

Ikhsania, A. A. (2020). Siapa Saja Orang Yang Rentan Covid-19 dan Lebih Beresiko?. https:// www.sehatq.com/ artikel/ siapa-saja-orang-yang-rentan-terinfeksivirus-corona. 15 Oktober 2020.

Lawless, J. F. (2003). The Statistical Analysis of Recurrent Event. USA : Springer Scince Business Media Inc.

KemenkesRI. (2020). Kementerian Kesehatan RI, Covid-19 Dalam Angka, Kondisi 22 Agustus 2020. Jakarta : KemenkesRI Press

Kementerian Kesehatan Republik Indonesia. 2020. Kesiapan Kemenkes Dalam Menghadapi Outbreak Novel Coronavirus (2019-nCoV). Simposium PAPDI Forum, 29 Januari 2020. Kemenkes RI. Jakarta.

Pemkabjember.(2020). Gugus Tugas Penanganan Covid-19. Instagram pemkabjember @pemkabjember. 30 Agustus 2020.

Suhartini, A., Rahmawati, R., \& Suparti. (2018). Analisis Kurva Survival Kaplan Meier Menggunakan Uji Log Rank (Studi Kasus: Pasien Penyakit Jantung Koroner di RSUD Undata Palu). Jurnal Gaussian, Volume 7, Nomor 1, 33-42. 